\title{
IAMJ
}

INTERNATIONAL

AYURVEDIC

MEDICAL JOURNAL

Review Article

ISSN: 2320-5091

Impact Factor: 6.719

\section{ROLE OF KSHEERA AND GHRITA AS RASAYANA FOR BETTER HEALTH OF CHILDREN}

\section{Naseeba $\mathrm{C}^{\mathbf{1}}$, $\underline{\text { Jithesh Chowta }}^{2}$}

${ }^{1}$ Final year PG Scholar, Dept. of Kaumarabhritya, Alva's Ayurveda Medical College, Moodbidri, Karnataka, India

${ }^{2}$ Assistant Professor, Dept. of Kaumarabhritya, Alva's Ayurveda Medical College, Moodbidri, Karnataka, India

Corresponding Author: drnaseebas@gmail.com

\section{https://doi.org/10.46607/iamj3409102021}

(Published Online: October 2021)

Open Access

(C) International Ayurvedic Medical Journal, India 2021

Article Received: 28/09//2021 - Peer Reviewed: 07/10/2021 - Accepted for Publication: 08/10/2021

\section{Check for updates}

\section{ABSTRACT}

Rasayana is one among the divisions of Ashtanga Ayurveda that primarily deals with the maintenance of health. The aim of Ayurveda is prevention and promotion of health and secondly to cure disease. This can be achieved through Rasayana. It improves immunity and performs many vital functions of the human body. Rasayana therapy which is given to children is known as Bala Rasayana. Ghrita and Ksheera are mentioned as Ajasrika Rasayana. Ajasrika Rasayana is one among the classifications of Rasayana, which when used regularly provide nourishment to Rasa-raktadi dhatus and which in turn enhances Ojas. In this developing world, the rate of occurrence of the disease is more, about $24 \%$ of individuals below the age of 19 years fell sick over three times a year according to a large-scale survey conducted across India in 2019. As children are easily exposed to various disease-causing agents due to low immunity, thus the development of strong immunity is important. It can be achieved through Rasayana which helps to maintain a strong and vital immune system.

Keywords: Rasayana, Ksheera, Ghrita, Ajasrika Rasayana, immunity 


\section{INTRODUCTION}

Kaumarabhritya is one of the branches of Ashtanga Ayurveda. It deals with prenatal care till the child completes Kumaravastha. The aim of this branch is better development of children as they are easily prone to many infectious diseases because of the immature immune system. Thus, to increase the immunity of children, the knowledge of proper administration of $R a$ sayana is sufficient.

According to Acharya Sushrutha ${ }^{1}$, Rasayana tantra deals with Vayasthapana, Medhya, Balakara and Rogahara. The word Rasayana consists of two words 'Rasa' and 'Ayana'. The literal meaning of the word Rasa means first Dhatu or nutrition and Ayana means Marga or Path. Thus, Rasayana means Rasa and its transportation in the body. The prime function of $R a$ sayana is the nourishment of every cell or tissue of the body. It maintains the longevity of life, increases vitality and mental health.

The definitions for Rasayana are:

- "Labhobayo hi shasthanaam rasadheenaam rasayanam / "3- It means one which nourishes the Rasa Dhatu is known as Rasayana.

- "Yath jaravyadhi vidhwamsi bheshajam tad rasayanam l"4 - It means Bheshaja which cures the Vyadhi, as well as Jara, is known as Rasayana. Acharya Dalhana 5 in his commentary on Sushrutha Samhita in "Sarvopaghata Samanya Rasayana" chapter mentions the term Rasayana in two ways:

$>$ Kutipravesika: residing in a specially built home and undergoing therapy.

> Vataatapika: undergoing therapy while moving about in wind and sunlight.

Further, it is again of three types:

$>$ Kamya Rasayana- desiring benefits such as long life, great intelligence, wealth etc.,

$>$ Naimittika Rasayana- consequent to diseases such as the use of recipes of Silajatu, Bhallataka, Tuvaraka etc. in diseases like Prameha, Kushta etc.

> Ajasrika Rasayana-habitual-to be consumed daily such as milk, ghee etc.,
Ajasrika Rasayana refers to continuous usage of a nutritious diet to maintain optimum nutrition by way of direct nourishment i.e., intake of Ksheera and Ghrita regularly. Among the three, Kamya and Ajasrika Rasayana are best indicated for Kumaraas because they are in a condition of Aparipakwadhatu. The application of these helps to promote the health of their Dhatu from the very beginning. That is why Vagbhata commented as 'Purvae vayasi madhyae va...' $\left.\right|^{6}$. Ajasrika Rasayana is one of the classifications of Rasayana which are given in the form of nutrition by means of dietary regimens, which are extensively utilized on day-to-day basis. Ghrita and Ksheera which are used daily influence Rasayana hence these are considered as Ajasrika Rasayana ${ }^{7}$. Ajasrika Rasayana when used regularly provide nourishment to Rasa-raktadi dhatus and which in turn enhances Ojas $^{8}$. According to Acharya Charaka, "Ksheeraghrtaabhyaso rasayananaam I "i.e., intake of Ksheera and Ghrita are considered as Rasayana

\section{Ksheera}

There are various synonyms of milk ${ }^{10}$. They are Ksheera, Piyusha, Udhastha, Stanya, Paya and Amrutha. Stanya is the first feed which the child obtains soon after birth. Stanya is considered as an Upadhatu of Rasadhatul . It is produced from Ahara Rasa ${ }^{12}$. Stanya is Prasada baga of Rasa dhatu, Madhura rasa and generated from digested food. Ideal milk must have normal Prakrthi Varna, Gandha, Rasa and Sparsha, dissolved absolutely in water because of its watery nature. Ideal milk provides nourishment and disease-free i.e., healthy state to the child ${ }^{13}$. If breast milk is insufficient, the child may be given milk of wet nurse, goat's milk, or cow's milk because in general milk is suitable to the child. In Ashtanga Hridaya, the milk should be processed with drugs of Hrswa Panchamula (roots of Shalaparni, Prishniparni, Brihati, Kantakari and Gokshura) or with two Sthira and mixed with sugar can be given in the non-availability of breast milk. Breast milk completely satisfies an infant's nutritional and fluid needs for the first six months. 
Table 1: Properties of different Ksheera

\begin{tabular}{|l|l|}
\hline \multicolumn{1}{|c|}{ Ksheera } & Properties \\
\hline Gavya Ksheera & $\begin{array}{l}\text { Madhura rasa, Sheeta veerya, Mridu, Snigdha Bahala, Guru, Manda, Prasanna, acts as Rasayana } \\
\text { and Ojo vardhaka. }\end{array}$ \\
\hline Aja Ksheera & $\begin{array}{l}\text { Kashaya Madhura rasa, Laghu Guna, Sheeta veerya, Malasangraha, cures Raktapitta, Atisara, } \\
\text { Kshaya, Kasa, and Jwara. }\end{array}$ \\
\hline Mahisha Ksheera & Guru guna, Sheeta Veerya, Mandagnikaraka, Sneha, cures Anidra \\
\hline Ushtra Ksheera & Ruksha, Ushna veerya, Lavana, Laghu, cures Vata kaphaja rogas, Anaha, Krimi, Shotha, Arshas \\
\hline Aavika Ksheera & Ushna Veerya, Kapha pitta karaka, causes Hikka, Shwasa \\
\hline Ashwa Ksheera & Ushna Veerya, Bala vardhaka, Stairyakara, cures Shakhagata Vata, Madhura Amla lavana rasa, \\
& Ruksha Ushna Laghu Guna \\
\hline Maanushi Ksheera & Vata pitta Raktaja vikara, Akshiroga, Abhighata \\
\hline Hasti Ksheera ${ }^{21}$ & Balya, Guru, Stairyakara \\
\hline
\end{tabular}

- The general properties ${ }^{22}$ of Ksheera are Madhura Rasa, Guru, Pichila, Snigdha, Shlakshana, Sara, Satmya, Mridu, Satmya

- It is Preenana, Brimhana, Vrishya, Medhya, Balya, Jeevaniya, Shramahara, Deepaniya, Pathya and Satmya.

- It is indicated in Shwasa, Kasa, Raktapitta, Trishna, Pandu, Amlapitta, Gulma, Shosha, Udara, Atisara, Jwara, Daha, Shwayathu, Yonivikara, Shukravikara, Gratita Purisha, Vatapitta vikara.

\section{Ksheera as Rasayana:}

Stanya is the Upadhatu of Rasadhatu, which is capable of Prinana for all seven dhatus and other body entities, similarly, Stanya does nourishment of the baby. Stanya is Satmya, Rasayana and results in Drdopachita Gaatra, reduces Meda and able to subside tiredness. ${ }^{23}$ The properties of Goksheera are Madhura rasa, Sheetavirya, Mridu, Snigdha, Bahala, Shlakshana, Guru, Manda and Prasanna qualities. These ten qualities are like Ojas. Acharya Charaka has mentioned that "Sarvada Sarva Bhavanam Samanyam Vriddhikaranam" 24 which means by consuming any Dravyas possessing similar properties in terms of Dravya, Guna and Karma are always increased or enhanced. Acharya Sushrutha has mentioned the use of "Swayonidravya Prayoga" in Dhatu Kshayaavastha which means that any substance possessing similar qualities as that of Dhatu is going to increase that Dhatu by consuming the Dravyas of the same qualities. By use of Goksheera, which in turn helps to increase Ojas in our body which are having similar properties. Thus, from the above points, one can understand that Goksheera acts as Rasayana. Acharya Charaka has mentioned that Godughdha possessing ten gunas are like the gunas of Ojas, thus it leads to an increase in Ojas, which is very essential Dhatu in our body ${ }^{25}$. Goksheera is considered as Shrestha Rasayana as it is the best among all Jeevaniya Padarthas. Among all, Goksheera is considered as best Rasayana dravya as it can be used as a dietary supplement for all age groups, and it is considered as a balanced diet. According to Acharya Sushrutha, Goksheera is Alpabhishyandhi ${ }^{26}$ and whereas according to Acharya Charaka ${ }^{27}$, Goksheera is considered as Jeevaniya and performs Ojovardhana and Rasayana actions.

Milk acts as an important source of a diet in children as it contains nutrients to help in the development of bones, regulate blood pressure and maintain a healthy weight. Milk contains essential nutrients which help to support a child's growing body, including high-quality protein, calcium, potassium, Vitamin D, Vitamin B12, Vitamin A, Phosphorus, Vitamin B2 and Vitamin B3. Children with lower levels of vitamin D especially during the younger years will suffer a disease i.e., rickets and poor growth. Cow's milk is one of the best ways to replenish this vitamin and plays a key role in keeping the child healthy ${ }^{28}$. Colostrum in breastmilk contains antibodies called immunoglobulins. These immunoglobulins are passed from mother to baby. They are kind of proteins. Breast milk contains the immunoglobulins IgA, IgM, IgG, and secretory versions 
of $\operatorname{IgM}(\operatorname{SIgM})$ and $\operatorname{IgA}(\mathrm{SIgA})$. Colostrum contains a high amount of SIgA, which protects the baby by forming a protective layer in the nose, throat and digestive system $^{29}$. Milk from grass-fed cows is known to have higher omega-three fatty acids content (particularly C 18:3 Linolenic acid) and higher conjugated linoleic acid content than cow feds on supplementary feeds. The milk has higher levels of vitamin $\mathrm{E}$ and beta-carotene. Also contains higher natural vitamin $\mathrm{D}$ due to cows' exposure to sunlight. Milk and dairy products from grass-fed cows are not only great sources of nutrition but are also common for people to consume probiotics and prebiotics. These help in boosting immunity by promoting the growth of beneficial bacteria in the gut. A healthy interaction between the immunity system and gut microbiota is crucial for the maintenance of health in our body ${ }^{30}$.

\section{Ghrita}

The synonyms of ghee are Ghrita, Ghritam and Sarpi. The Properties of Ghrita are

- Rasa: Madhura rasa

- Guna: Snigdha, Mridu, Shlakshana, Guru

- Veerya: Sheeta Veerya

- Vipaka: Madura Vipaka

\section{- Doshagnatha: Tridosha shamaka}

According to Acharya Charaka ${ }^{31,32}$, Ghrita is Pittanilaharam, Rasa, Shukra and Ojo hitam, Niravapanam, Mrdukaram, Swaravarna prasadanam, Kapha Medo Vivardhanam, Smruthi Budhi vardhakam and Agni vardhakam. According to Acharya Sushrutha ${ }^{33}$, Ghrita is Madhura, Saumya, Guru and Mrdu Guna, Sheeta veerya, Anabhishyandi, Snehana, Vatapitta Prashamana, Agni deepana, Smriti medha Kanthi Swara Lavanya Saukaumarya Oja Teja Balakara, Ayushya, Vrushya, Chakshushya, Shleshma Vardhaka, Papma, Alakshmi Prashamana, Vishahara and Rakshoghna, According to Ashtanga Hridaya $^{34}$, Ghrita possess Dhi, Smruthi, Medha, Agni, Bala, Ayu, Shukra-Chakshushya, Kanthi swararthinam, Saukaumarya, Sheetam, Vayasthapanam, Praja, Snehanamuttamam, Sahasraveeryam, and Karmasahasrakrut.

\section{Purana Ghrita-}

$>$ According to Acharya Charaka ${ }^{35}$, Ghrita which is preserved for ten years is referred to as Purana Ghrita. It has Gunas such as Sara, Katu Vipaka, Tridoshahara, Katu Tikta in Rasa, Ugra Gandha, Laksha-Rasa-Nibam, Sheeta, Medhya, Chedi, and Teekshna. It alleviates Mada, Apasmara, Murcha, Shosha, Unmada, Visha, Jwara and Shoola in Yoni, karna and Shiras.

> Acharya Vaghbata particularly mentions the Vrana Shodhana and Ropana action for Purana Ghrita.

\section{Prapurana Ghrita}

$>$ The Ghrita which is preserved for more than ten years is referred to as Prapurana Ghrita.

$>$ This Ghrita possess properties which are like that of Laksha rasa, which is Sheeta Veerya, Graha dosha shamaka, budhi vardhaka and is excellent for Virechana. ${ }^{36}$

\section{Ghrita as Rasayana:}

The properties of Ghrita are Madhura, Snigdha, Guru Guna and Sheeta Veerya which helps to increase Agni deepana which helps in Pachana or digestion of Ahara rasa. This leads to nourishing the foremost Dhatu i.e., Rasa Dhatu and all other Dhatus. Therefore, when all dhatus are nourished, the essence of Saptadhatu i.e., Ojas also gets enhanced. Thus, Ghrita acts as Ajasrika Rasayana which yields Ayuprakarsha, Swara Varna prasadana, Medhya, Chakshushya, Shukravardhaka etc. Ghee is a good source of energy for children. It contains saturated fatty acids, which provide energy as well as stamina. It helps in brain development. It also contains mono-saturated Omega-3s, fat-soluble vitamins A, D, E and K, large quantities of butyrate, a fatty acid that has been linked to an immune system response for inflammation management. Ghee also improves gut health, which is directly linked to building immunity ${ }^{37}$. Ghee helps in improving digestion, increases memory and intellect, improves skin and eye health along with that, acts as a lubricant for joints. As it is a good source of butyrate fatty acids which is essential for preventing diseases of the digestive system. 


\section{DISCUSSION}

Rasayana dravya is digested by Jatharagni which is followed by Butagni and Dhatuvagni. During Sara Kitta Vibhajana, Ahara Rasa is produced along with Vata, Pitta and Kapha Doshas. This qualitative Ahara Rasa produces pure Rasa Dhatu, which then continues the chain of production of other Raktadi dhatus with the help of respective Dhatwagni up to Ojas formation. This well-formed dhatus nourishes the body according to its intake. Rasayana dravya also influences Ojas, which increases Shareera Bala.

- At the level of Dhatu, Rasayanadravyas acts by improving the nutritional values of Poshaka rasa. Probably Rasayana dravyas are having Madhura, Guru, Snigdha and Sheeta gunas which act as Rasayana by promoting the nutritional value of Rasa which in turn helps in obtaining Dhatus having best qualities.

- At the level of Agni, Rasayanadravyas acts by improving digestion and creating the excellence of Saptadhatu.

- At the level of Srotas, Rasayanadravyas acts by cleaning and activation the microcirculatory channel that is Srotoshuddhi leading to improve microcirculation.

The properties of Ksheera are like Ojas, hence it is responsible for Ojovardhana. Thus, it increases the Bala and Vyadhikshamatva of an individual and helps in attaining longevity.

Similarly, Ghrita is also Ojo vardhaka as it is Agnideepaka and helps in Pachana and proper formation of Ahara Rasa, hence helping in the nourishment of Rasaadi Dhatus. Acharya Sushrutha has mentioned the use of Sheetodaka, Ksheera, Madhu, and Sarpi separately or in combination having Rasayana action as well as Ayusthapana action. The important character of Ghrita is 'Samskarasya Anuvarthanam'38 i.e., power to assimilate the Gunas of other substances effectively with which it is processed. Also, Ghrita does not give up its properties even if it is mixed with substances possessing other properties. It improves digestive power and other qualities are related to milk. Ghrita Kalpana plays a key role in the treatment of various diseases. So Ghrita consumption should be done daily. By following Ajasrika Rasayana i.e., consuming Ghrita and Ksheera one can prevent and cure disease and promote health. It acts as an immune modulator as well as the best diet.

\section{CONCLUSION}

According to Ayurveda, preservation of health and manifestation of disease mainly depends on how a person maintains quality and quantity of food along with lifestyle, psychological status, and effect of environmental conditions. Thus, quality and quantity of food play a major role in the maintenance of health with due consideration of the status of Agni, suitability of individuals depending on Prakriti. This can be achieved through Ajasrika Rasayana, by giving suitable healthy food. Through Rasayana Chikitsa, one can influence the Dhatu, Agni and Srotas in our body. Thus, $R a$ sayana is a unique treatment in influencing the fundamental aspects of the body. By proper intake of $R a$ sayana Dravya, one can bring about proper growth and improvement of Sapta dhatu, which ultimately increase Ojas. Thus, there is the regeneration of cells and body tissues which leads to an increase of Ojas. As we know in this developing world, with increasing pollution, improper lifestyle, intake of fast foods, unhygienic living conditions, improper food habits; the chance of occurrence of infectious diseases is also increasing. Children are easily exposed to various disease-causing agents and thus gets affected badly. This leads to exposure to disease at an early age; can affect the whole life and sometimes results in chronic disorders. Thus, the development of a strong immune system is important. It can be achieved through Rasayana, and it helps to maintain a strong and vital immune system. Rasayana Chikitsa is used as a preventive remedy in children since it enhances immunity and thus protects them from various infectious diseases. Ayurveda described Rasayana for Balaroga with great care since Rasayana Chikitsa may become harmful in children if not used properly but Ajasrika Rasayana is an exemption for this. Ajasrika Rasayana is the best method to adopt in daily routine as there is no need for any Shodhana process. Thus, consuming Ghrita and Ksheera 
are considered a simple method of practising $R a$ sayana, which helps to restore immunity naturally.

\section{REFERENCES}

1. Sushrutha, Sushrutha Samhita with the Nibandha Sangraha Commentary by Sri Dalhanacharya and the Nyayachandrika Panjika by Sri Gayadasacharya on Nidanasthana. Edited by Vaidya Jadavji Trikamji Acharya from the beginning to the nine adyaya of Chikitsa sthana and the rest by Narayan Ram Acharya kavyatortha'. Chaukhamba Sanskrit Sansthan; Varanasi, Reprint 2009, Sutra sthana chapter: first shloka: $15^{\text {th }}$, Pg.no-3.

2. Waman Apte. Sanskrit-Hindi Shabdakosha. Reprint. New Delhi: Anil Prakashana; 2007. Rasayana. Page No. 94.

3. Acharya Vagbhata, Ashtanga Hridaya with Sasilekha commentary of Indu edited by Astavaidya Vaidyamadhom Cheriya, Narayanan Namboodiri and Math, Chaukambha Krishnadas Academy, Varanasi, reprint: 2007, Chapter: 39 ${ }^{\text {th }}$, Page No 600.

4. Sri Chakrapanidatta, Chakradatta, $66^{\text {th }}$ chapter, 1-3 shloka, bhavaratnasandipini Hindi commentary by Sri jadishvaraprasad Tripathi, edited by bhishagratna pt. brahma Shankar Mishra, Chaukambha Sanskrit series office Varanasi, 2008, Page No: 546-547.

5. Acharya JT. Sushrutha Samhita of Sushrutha with Nibandha Sangraha Commentary of Sri Dalhanacharya and NyayachandrikaPanjika of Sri Gayadasacharya. Reprint. Varanasi: Chaukambha Sanskrit Sansthan; 2009, Page No. 498.

6. Acharya Vagbhata, Ashtanga Hrdaya Samhita, with Sasilekha commentary of Indu edited and forwarded by Ashtavaidyan Vaidyamadhom Cheriya, Narayanan Namboodriri, Math, Chowkhamba Krishnadas Academy, Varanasi, Uttarasthana, $39^{\text {th }}$ chapter, Shloka 3, Page no: 608.

7. Acharya JT, Sushrutha Samhita of Sushrutha with Nibandha Sangraha Commentary of Sri Dalhanacharya and Nyayachandrika Panjika of Sri Gayadasacharya, Varanasi, Chaukambha Sanskrit Sansthan, Reprint; 2009, Page no: 498.

8. Acharya Charaka, Charaka Samhita, Charaka Chandrika English commentary of Agnivesha, edited by Dr Ram Karan Sharma and Vaidya Bhagwan Dash, Chaukambha Krishnadas Academy, Varanasi, Reprint; 2008, Sutrasthana $25^{\text {th }}$ Chapter, Shloka No-40, Page No: 426.
9. Pandit Narahari, Raj Nighantu, redacted by Indradeva Tripathi, Chaukhamba Krishnadas Academy Varanasi, edition; 2003, Ksheeradi Varga, Shloka No-1, Page no: 505.

10. Acharya Charaka, Charaka Samhita, Charaka Chandrika Hindi commentary of Agnivesha, edited by Dr Brahananda Tripathi, Chaukambha Surabharati Prakashana, Varanasi, Reprint; 2002, Sutrasthana, 27 Chapter, Shloka No: 217-218, Page No: 526.

11. Acarya Sharangadhara, Sharangadhara Samhita, Translated by $\operatorname{Dr}$ P. Himsagara Chandra Murthy, Chowkhambha Sanskrit series office, Varanasi, Reprint edition; 2010, Purva Khanda, Chapter: fifth, Shloka no: 16-17, Page no: forty-three

12. Vagbhata, Ashtanga Sangraha, Shareera sthana second chapter, Shloka No: thirty-three, Vol II, Text, English translation, translated by Prof. K. R Srikantha Murthy, Chaukambha Orientalia, Varanasi.

13. Acharya Charaka, Charaka Samhita, Shareera sthana Chapter $8^{\text {th }}$, Shloka No: 54, by Agnivesha revised by Caraka and Drdhabala with the Ayurveda- Dipika Commentary of Cakrapanidatta edited by Vaidya Jadavji Trikamji Acarya, Krishnadas Academy, Varanasi, reprint edition: 2000, Page No: 351.

14. Acharya Charaka, Charaka Samhita, Sutrasthana $27^{\text {th }}$ Chapter, Shloka No-222, Charaka Chandrika Hindi commentary of Agnivesha, edited by Dr Brahananda Tripathi, Chaukambha Surabharati Prakashana, Varanasi, Reprint, 2002; Page No: 527.

15. Acharya Charaka, Charaka Samhita, Sutrasthana $27^{\text {th }}$ Chapter, Shloka No-219, Charaka Chandrika Hindi commentary of Agnivesha, edited by Dr Brahananda Tripathi, Chaukambha Surabharati Prakashana, Varanasi, Reprint, 2002; Page No: 526.

16. Acharya Charaka, Charaka Samhita, Sutrasthana $27^{\text {th }}$ Chapter, Shloka No-220, Charaka Chandrika Hindi commentary of Agnivesha, edited by Dr Brahananda Tripathi, Chaukambha Surabharati Prakashana, Varanasi, Reprint, 2002; Page No: 526.

17. Acharya Charaka, Charaka Samhita, Sutrasthana $27^{\text {th }}$ Chapter, Shloka No-223, Charaka Chandrika Hindi commentary of Agnivesha, edited by Dr Brahananda Tripathi, Chaukambha Surabharati Prakashana, Varanasi, Reprint, 2002; Page No: 527.

18. Acharya Charaka, Charaka Samhita, Sutrasthana $27^{\text {th }}$ Chapter, Shloka No-221, Charaka Chandrika Hindi commentary of Agnivesha, edited by Dr Brahananda Tripathi, Chaukambha Surabharati Prakashana, Varanasi, Reprint, 2002; Page No: 527. 
19. Acharya Charaka, Charaka Samhita, Sutrasthana $27^{\text {th }}$ Chapter, Shloka No-224, Charaka Chandrika Hindi commentary of Agnivesha, edited by Dr Brahananda Tripathi, Chaukambha Surabharati Prakashana, Varanasi, Reprint, 2002; Page No: 527.

20. Acharya Sushrutha, Sushrutha Samhita, Purvardha, Sutrasthana $45^{\text {th }}$ chapter, Shloka No-48-49, Ayurveda Tatva Sandipika, Hindi commentary, edited by Kaviraja Dr Ambikadatta Shastry, Chaukambha Sanskrit Samsthan, Varanasi, Reprint, Page No: 222.

21. Acharya Charaka, Charaka Samhita, Sutrasthana $27^{\text {th }}$ Chapter, Shloka No-223, Charaka Chandrika Hindi commentary of Agnivesha, edited by Dr Brahananda Tripathi, Chaukambha Surabharati Prakashana, Varanasi, Reprint, 2002; Page No: 527.

22. Agnivesha, Charaka Samhita, Ayurveda Dipika Commentary by Chakrapanidatta, edited by Vaidya Yadavji Trikamji Acharya, Chaukhamba Orientalia, Varanasi, Reprint- 2015, Pg-9.

23. Kashyapa Samhita or Vrddhajivakiya tantra, Khila sthana, Text with English Translation and Commentary, edited by Prof. P.V. Tewari, Translation and commentary by Prof. P.V. Tewari with Dr Neeraj Kumar, Dr R.D. Sharma, and Dr Abhimanyu Kumar, Chaukambha Visvabharati, Varanasi, Reprint edition: 2018, Chapter: $5^{\text {th }}$, Shloka:49, Page No: 494.

24. Agnivesha, Charaka Samhita, Ayurveda Dipika Commentary by Chakrapanidatta, edited by Vaidya Yadavji Trikamji Acharya, Chaukhamba Orientalia, Varanasi, Reprint- 2015, Pg-165.

25. Sushrutha, Sushrutha Samhita, Nibandha Sangraha commentary by Sri Dalhanacharya, edited by Vaidya Jadavji Trikamji Acharya, Chaukambha Sanskrit Sansthan, Varanasi, Reprint-2012, Pg-201.

26. Agnivesha, Charaka Samhita, Ayurveda Dipika Commentary by Chakrapanidatta, edited by Vaidya Yadavji Trikamji Acharya, Chaukhamba Orientalia, Varanasi, Reprint- 2015, Pg-165.

27. https://www.childrens.com/health-wellness/what-isthe-best-milk-for-children

28. https://www.healthline.com/breast-milk/immunity

29. https://www.fonterra.com/nz/en/what-we-standfor/trusted-goodness/grass-fed.html

30. Acharya YT. Charaka Samhita with Ayurveda Deepika Commentary of Chakrapanidatta. Reprint. Varanasi: Chaukambha publication; 2011. p.82.

31. Acharya YT. Charaka Samhita with Ayurveda Deepika Commentary of Chakrapanidatta. Reprint. Varanasi: Chaukambha publication; 2011. p.166.
32. Acharya JT. SusrutaSamhita of Sushrutha with Nibandha Sangraha Commentary of Sri Dalhanacharya and Nyayachandrika Panjika of Sri Gayadasacharya. Reprint. Varanasi: Chaukambha Sanskrit Sansthan; 2009.p. 204.

33. Paradakara HSS. Ashtanga Hridaya with Sarvangasundara Commentary of Arunadatta and Ayurvedarasayana Commentary of Hemadri. Reprint. Varanasi (India): Chaukambha Orientalia; 2011.p.73.

34. Acharya Charaka, Charaka Samhita, Sutrasthana $27^{\text {th }}$ Chapter, Shloka No-231-233, Charaka Chandrika English commentary of Agnivesha, edited by Dr Ram Karan Sharma and Vaidya Bhagwan Dash, Chaukambha Krishnadas Academy, Varanasi, Reprint, 2008; Page No: 537.

35. Acharya Charaka, Charaka Samhita, Vidyotini Hindi commentary by pt. Kasinath Shastry edited Dr Gangasahaya Pandeya, Varanasi Chaukambha Sanskrit series, eighth edition, 2004 Chikitsa sthana ninth chapter verse 59-62, pp-265.

36. Acharya Charaka, Charaka Samhita, Vidyotini Hindi commentary by pt. Kasinath Shastry edited Dr Gangasahaya Pandeya, Varanasi Chaukambha Sanskrit series, eighth edition, 2004 Chikitsa sthana ninth chapter verse 59-62, pp-265.

37. https://www.architecturaldigest.in/ghee-immunity

38. Acharya YT. Charaka Samhita with Ayurveda Deepika Commentary of Chakrapanidatta. Reprint. Varanasi: Chaukambha publication; 2011. Page No: eighty-two.

\section{Source of Support: Nil Conflict of Interest: None Declared}

How to cite this URL: Naseeba C \& Jithesh Chowta: Role Of Ksheera And Ghrita As Rasayana For Better Health Of Children. International Ayurvedic Medical Journal \{online\} 2021 \{cited October 2021\} Available from: http://www.iamj.in/posts/images/upload/2506_2512.pdf 